\title{
Effect of organic carbon addition on paddy soil organic carbon decomposition under different irrigation regimes
}

Heleen Deroo ${ }^{1,2}$, Masuda Akter ${ }^{3}$, Samuel Bodé ${ }^{2}$, Orly Mendoza ${ }^{1}$, Haichao Li ${ }^{1}$, Pascal Boeckx $^{2}$, Steven Sleutel ${ }^{1}$

${ }^{1}$ Department of Environment, Ghent University, Ghent, Belgium

${ }^{2}$ Isotope Bioscience laboratory, Department of Green Chemistry and Technology,

Ghent University, Ghent, Belgium

${ }^{3}$ Soil Science Division, Bangladesh Rice Research Institute, Gazipur, Bangladesh

Correspondence to: Heleen Deroo (Heleen.Deroo@UGent.be)

Supplementary material S1: Evolution of the $\delta^{13} \mathrm{C}$ of emitted $\mathrm{CO}_{2}$ and $\mathrm{CH}_{4}$
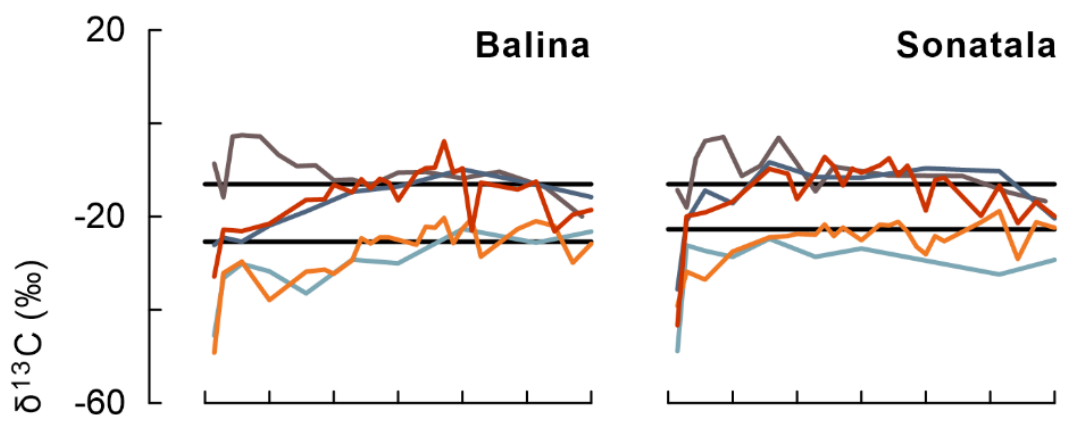

$\left.\begin{array}{ll}\begin{array}{ll}\delta^{13} \mathrm{C}-\mathrm{CO}_{2} \mid \mathrm{CF} \\ \delta^{13} \mathrm{C}-\mathrm{CO}_{2} \mid \text { AWD }\end{array} & \begin{array}{l}\text { Maize - C } \\ \text { SOC }\end{array}\end{array}\right\}$ Solid OC

$\delta^{13} \mathrm{C}-\mathrm{CO}_{2}$ maize (without SOC)

$\delta^{13} \mathrm{C}-\mathrm{CO}_{2 \mid \mathrm{SOC}} \mid \mathrm{CF}$ ) Un$\delta^{13} \mathrm{C}-\mathrm{CO}_{2 \mid \operatorname{soc}} \mid$ AWD $\}$ amended
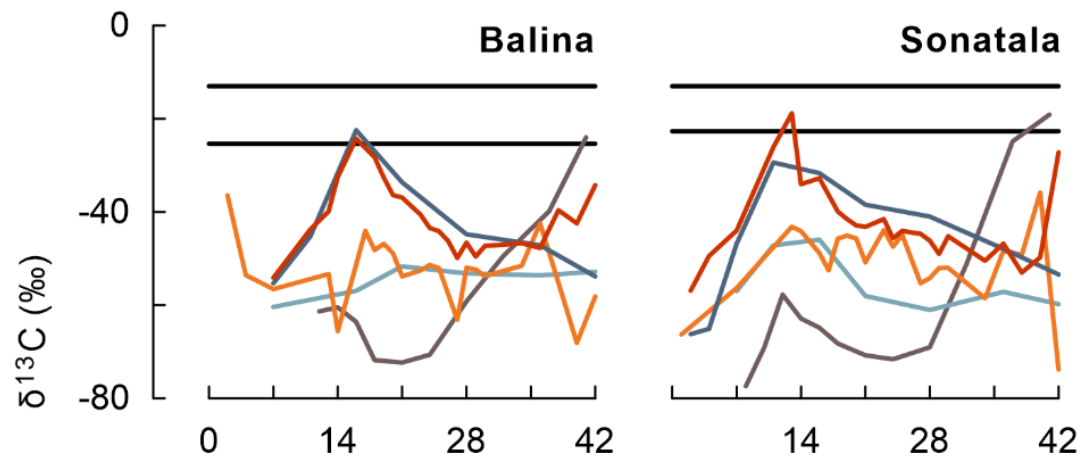
Maize - C
SOC
$\delta^{13} \mathrm{C}-\mathrm{CH}_{4} \mid \mathrm{CF}$
$\delta^{13} \mathrm{C}-\mathrm{CH}_{4}$ | AWD
$\delta^{13} \mathrm{C}-\mathrm{CH}_{4 \mid \text { maize }}$
$\delta^{13} \mathrm{C}-\mathrm{CH}_{4 \mid \text { soc | CF }}$
$\delta^{13} \mathrm{C}-\mathrm{CH}_{4 \mid \text { sOc }}$ AWD

DAT

Figure S1. Addition of maize affected the $\delta^{13} \mathrm{C}$ of emissions, as indicated by the progression of $\delta^{13} \mathrm{C}$ signatures (average of two or three replicates) of $\mathrm{CO}_{2}$ (upper graph) and $\mathrm{CH}_{4}$ (lower graph) emissions derived from the maize-amended paddy soils (dark blue and red) compared to those from control pots without maize (light blue and orange) versus of the ancillary maize incubation in substrate without native SOC (grey). The standard error was on average $2.0 \%$. The endmembers referring to emissions derived from only SOC and only maize take into account isotopic fractionation during decomposition of solid native SOC and maize respectively $\left(\delta^{13} \mathrm{C}\right.$ : black lines), and are hence a better reference for source partitioning of emissions. It was particularly for $\mathrm{CH}_{4}$ emissions difficult to trace back the original $\delta^{13} \mathrm{C}$ contrast in solid maize versus SOC after C-isotopic 
fractionation during decomposition and transport. The values of $\delta^{13} \mathrm{C}_{-} \mathrm{CO}_{2}$ maize and $\delta^{13} \mathrm{C}-\mathrm{CH}_{4}$ |maize were determined in ancillary incubations as described below.

An ancillary six-week incubation experiment with maize as the only OC source was set up to estimate $\delta^{13} \mathrm{C}-\mathrm{CO}_{2}$ maize and $\delta^{13} \mathrm{C}-\mathrm{CH}_{4}$ maize, so that these values could be used instead of the $\delta^{13} \mathrm{C}$ of solid maize-C as endmember for $\mathrm{C} 4$ to estimate the maize-derived fraction of emission fluxes (Werth and Kuzyakov, 2010; Conrad et al., 2012). Therefore, we filled PVC tubes (diameter: $6.8 \mathrm{~cm} \mid$ height: $7.2 \mathrm{~cm})$ with a mixture of $100 \mathrm{~g}$ sand $(0.18$ $-0.35 \mathrm{~mm}$ ) without $\mathrm{OC}$ (aimed for making grout), $4 \mathrm{~g} \mathrm{~kg}^{-1}$ maize, $6.6 \mathrm{~g} \mathrm{~kg}^{-1} \mathrm{Fe}^{3+}$ as $\mathrm{Fe}_{2} \mathrm{O}_{3}$ (equalling the oxalateextractable Fe concentrations in the Balina and Sonatala soil series), $0.043 \mathrm{~g} \mathrm{~kg}^{-1} \mathrm{~N}$ as NH $\mathrm{NO}_{3}, 0.007 \mathrm{~g} \mathrm{~kg}^{-1} \mathrm{P}$ as $\mathrm{Ca}_{3}\left(\mathrm{PO}_{4}\right)_{2}, 0.029 \mathrm{~g} \mathrm{~kg}^{-1} \mathrm{~K}$ as $\mathrm{KCl}$ (where the latter three equal the concentrations for the main pot experiment) and $60 \mathrm{~mL}$ soil inoculum from either Balina or Sonatala (three replicates each). The soil inoculum was obtained by shaking $30 \mathrm{~g}$ of paddy soil from either the Balina or Sonatala soil series with $80 \mathrm{~mL}$ deionised water during 2 hours, and subsequently centrifuging them at $1000 \mathrm{~g}$ for 15 minutes. Deionised water was added until a standing water table of $2 \mathrm{~cm}$, which was maintained throughout the experiment. The small mesocosms were incubated in a controlled temperature cabinet at $28{ }^{\circ} \mathrm{C}$ during 42 days. $\delta^{13} \mathrm{C}$ signatures of $\mathrm{CH}_{4}$ and $\mathrm{CO}_{2}$ were measured seventeen times by CRDS using a PVC gas flux chamber without fan (diameter: $6.8 \mathrm{~cm}$ | height: $7.2 \mathrm{~cm}$ ), and processed by means of the Keeling plot method (grey lines in Supplementary Fig. S1). 
Supplementary material S2: Evolution of the soil exchangeable $\mathrm{NH}_{4}{ }^{+}$
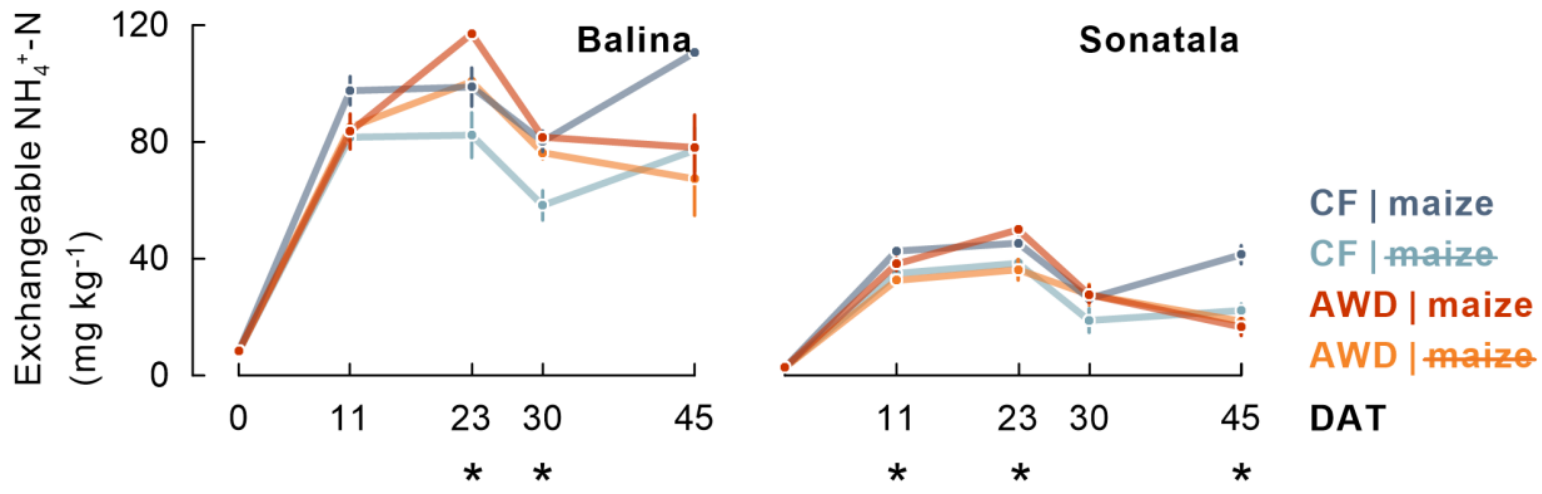

Figure S2. Irrigation management barely affected exchangeable ammonium $\left(\mathrm{NH}_{4}^{+}\right)$concentrations (average \pm standard error of three or two replicates), but the addition of exogenous maize shoots did often lead to somewhat higher concentrations. * indicates a significant effect of maize addition at the corresponding point in time. 
Supplementary material S3: Evolution of the soil pH
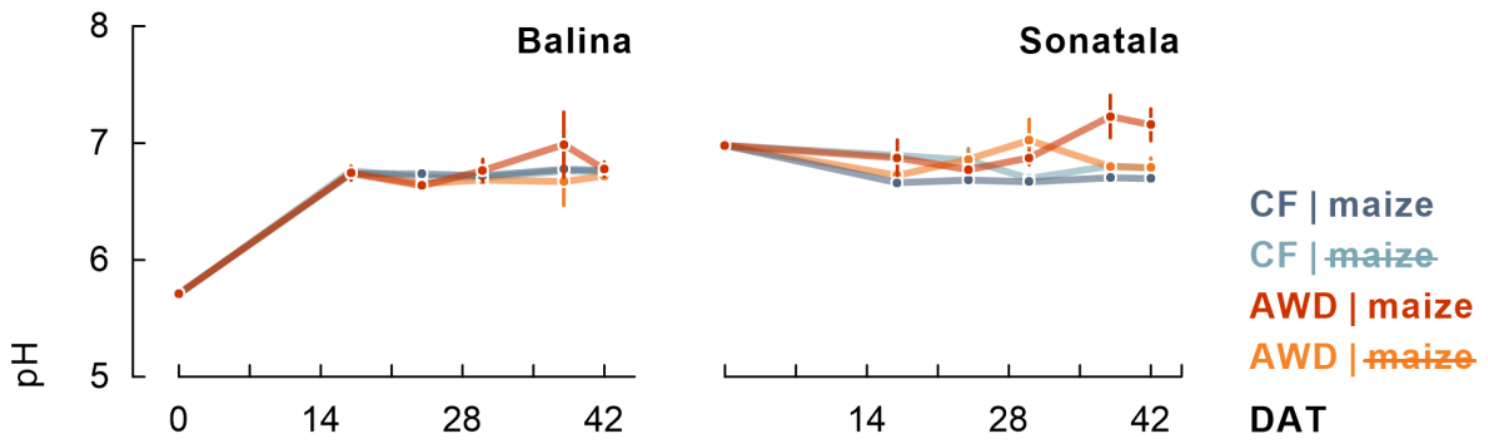

Figure S3. Soil pH (average \pm standard error of three or two replicates) increased over the course of the experiment in Balina soil. 